\title{
Measuring Malaysia school resource centers' standards through iQ-PSS: An online management information system
}

\author{
Fadzliaton Zainudin \\ Educational Technology Division, Ministry of Education of Malaysia, Persiaran Bukit Kiara, 50604 Kuala Lumpur, Malaysia Email \\ fadzliaton@moe.edu.my
}

Kamarulzaman Ismail

Educational Technology Division, Ministry of Education of Malaysia, Persiaran Bukit Kiara, 50604 Kuala Lumpur, Malaysia Email kamarulzaman@moe.edu.my

\begin{abstract}
The Ministry of Education has come up with an innovative way to monitor the progress of 9,843 School Resource Centers (SRCs) using an online management information system called iQ-PSS (Quality Index of SRC). This paper aims to describe the data collection method and analyze the current state of SRCs in Malaysia and explain how the results can be used to make informed decisions on further development and improvement of SRCs. The paper contributes to a deeper understanding of the factors that are involved in the process of achieving and maintaining the quality and excellence of SRC services to school children and at the same time, inculcating lifelong learning habits.
\end{abstract}

\section{Introduction}

The Integrated Curriculum for Primary Schools (KBSR), launched in 1983, and later, the Integrated Secondary School Curriculum (KBSM), commenced in 1987, stress on the appropriate use of a variety of educational resources and teaching methods to increase the quality of teaching-learning processes. Teachers are required to plan and integrate various sources of educational resources in their classrooms. The development of instructional technology leads to the establishment of the Educational Resource Centers at national, state, district and school levels to cater to these needs (Figure 1). Teachers and teacher-librarians are trained and encouraged to use resource-based materials and educational technology to increase the effectiveness of their teaching-learning processes (Yusup \& Razmah, 2005).

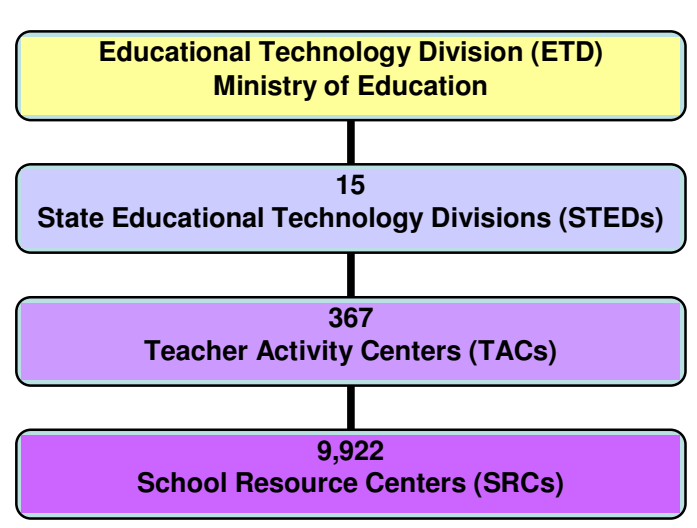

Figure 1. The Educational Technology Division and its network.

To ensure the success of the implementation of KBSR and KBSM in schools, programs and activities related to the Resource Centers are planned, implemented, coordinated and monitored by the ETD, STEDs and TACs. To step up efforts taken by all quarters and to show its seriousness, the Ministry of Education hopes to create awareness and encourage all schools to upgrade the SRCs by suggesting programs and activities related to the SRC such as the SRC Assistance Program and the SRC Excellent Award (Ministry of Education, 2000). To date, 269 SRCs participated in the SRC Assistance Program which is registered under MS ISO 9001:2008 to ensure

(C) 2010 IASL, SLAQ and therein by the authors. Diversity Challenge Resilience: School Libraries in Action Proceedings of the $12^{\text {th }}$ Biennial School Library Association of Queensland, the $39^{\text {th }}$ International Association of School Librarianship Annual Conference incorporating the $14^{\text {th }}$ International Forum on Research in School Librarianship, Brisbane QLD Australia, 27 September - 1 October 2010 . 
the quality and coordination of the program at state and district levels. On the other hand, 392 SRCs took part in the SRC Excellent Award at the national level since its inception in 2000 (Bahagian Teknologi Pendidikan, 2009). In short, continuous efforts and improvements are made to ensure the quality of educational resources to support the curriculum.

The Smart School concept strengthens the needs for quality educational resources, especially in the ICT sector, even further. Introduced in 1997, the Smart School transformed the landscape of Malaysian education system in support of the nation's aspiration to be a developed nation in all the dimensions: economically, politically, socially, spiritually, psychologically and culturally by 2020 (Ministry of Education, 1997). Vision 2020 is a Malaysian ideal introduced by the former Prime Minister of Malaysia, Tun Mahathir Mohamad during the tabling of the Sixth Malaysia Plan in 1991. In order to establish a competitive economy which is dynamic, robust and resilient, the economy must be technologically proficient, and driven by brain-power, skills and diligence in possession of a wealth of information, with the knowledge of what to do and how to do it (Mahathir, 1991). The transformation of Malaysian education system through the implementation of the Smart School means reinventing the culture and practices at schools which requires students to exercise greater responsibility for their own education and prepare them for the Information Age by making use of the presence of leading-edge technologies and ICT infrastructure in all components (Figure 2).

\section{The Smart School Components}

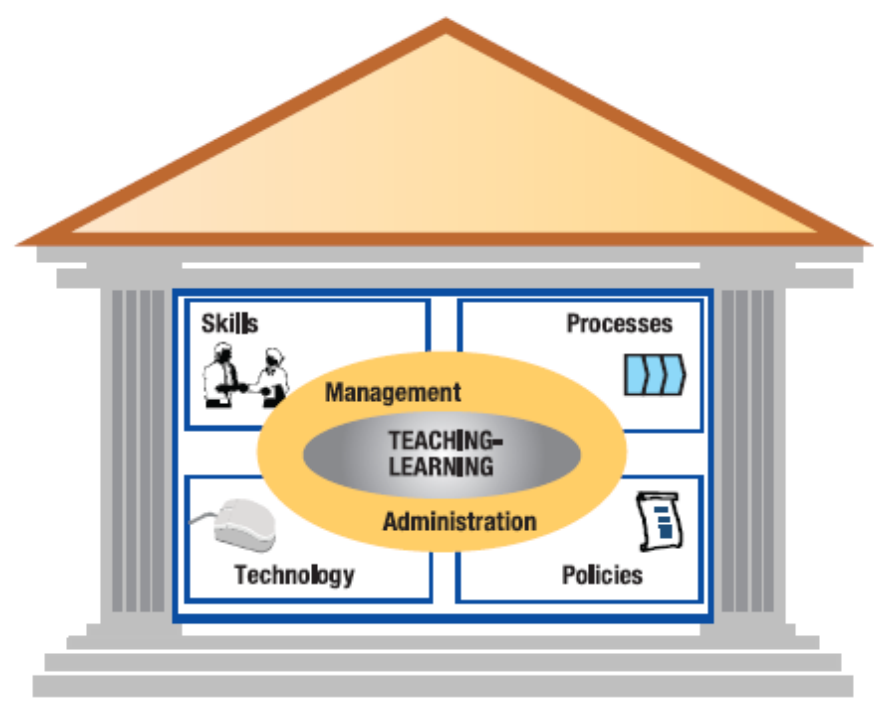

Figure 2. The Smart School components. Source: Kementerian Pelajaran Malaysia, 1997.

To achieve the Smart School objectives, efficient and effective management of educational resources and processes are required to support the teaching-learning functions. The evolution of resourced-based curriculum and the Smart Schools concept has made the management of the SRCs more important than ever in order to support the government's vision. Efforts to increase the quality of the SRC management thus the quality of resource-based and ICT-based teaching-learning processes are heightened to cater to this development. The SRCs need to be continuously monitored and upgraded, and the performance of SRCs has to be efficiently measured to ensure the success of the nation's aspiration. At the operational level, this also means getting the comprehensive information on the SRCs so that the correct form of assistance can be given and the needs of the users are met. For example, decisions have to be made regarding which SRCs should get more books, which SRCs need to be given priority in getting assistance or which SRCs are in need of library automation. An effective, productive, cost-cutting and time-saving SRC management tool is needed and based on the result of 
the cost-benefit analysis study, the Quality Index of SRC (iQ-PSS) is considered as a solution. (Bahagian Teknologi Pendidikan, 2008).

\section{The current scenario of school resource centers (SRCs) in Malaysia}

The SRCs provide information and ideas that are fundamental to function successfully in today's information and knowledge-based society. The SRCs equip students with information literacy skills and help them develop life-long learning habits, enabling them to be knowledgeable and responsible citizens.

Currently, there are 9,922 SRCs in Malaysia with a total student population of 5.4 million (3.1 million primary school students and 2.3 million secondary school students) as shown in Figure 3 (Kementerian Pelajaran Malaysia, 2010). As a rule of thumb, where there is a school, there will be a school resource center; be it in the urban, rural or remote area. However, the facilities provided by the schools differ, usually based on several factors such as the enrolment of students, locality, teacher-librarians' competencies, availability of space, financial support (grant) and the school administration's supports towards SRCs and SRCs programs.

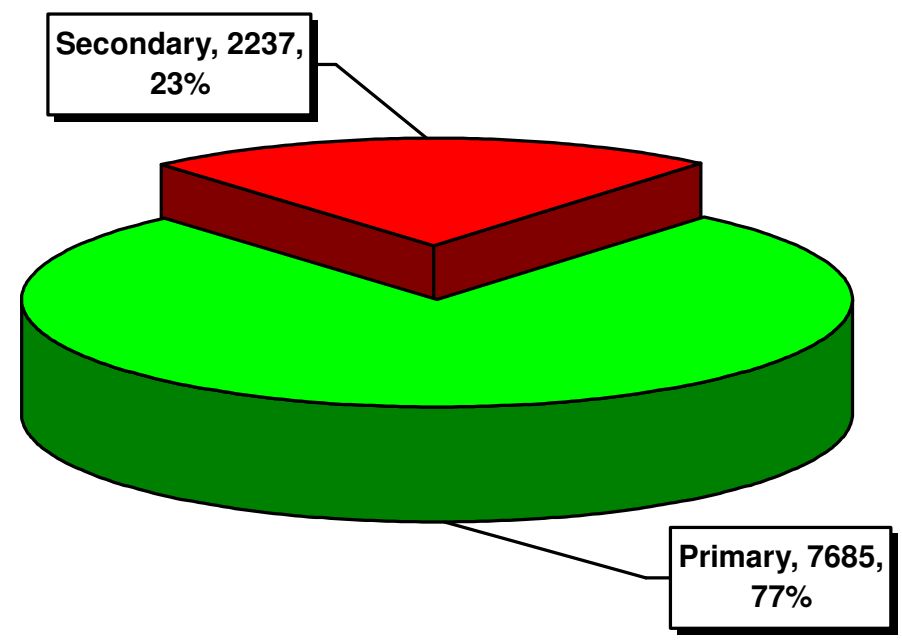

Figure 3. School resource centers in Malaysia. (Kementerian Pelajaran Malaysia, 2010)

An SRC generally consists of a minimum of three main rooms, that is, reading, audio-visual and teachinglearning materials. However, some schools especially those with a big population of students may extend the SRC network to more than these three basic rooms by including other rooms like self-access centers, science labs, computer labs and even classrooms as well. Beginning 1989 onwards, all newly built schools are given the whole floor of the building which is equivalent to four classrooms space for SRC (Fatimah, 2002).

Function of the SRCs

The SRCs aim to provide a range of learning opportunities for both large and small groups as well as individuals with a focus on intellectual content, information literacy, and the learner. In addition to classroom visits with collaborating teachers, the SRCs also serve as a place for students to do independent work, use computers, audio-visual equipment and materials; and also hold special events such as thematic exhibitions and reading club activities.

The SRC program is a collaborative venture in which the teacher-librarians, teachers, and administrators work together to provide opportunities for the social, cultural, and educational growth of students. Activities that are part of the SRC media program can take place in the SRC media center, and other SRCs' linked facilities such as 
the audio-visual room, computer laboratory, and School Access Centre and other special rooms set up by the schools.

\section{Management of SRCs}

An SRC is managed by a teacher-librarian who is also a full-pledged subject teacher. To ensure that teacherlibrarians have time to manage and organize the SRCs, the Ministry of Education appoints full-time teacherlibrarians in schools to support the implementation of SRC and Smart School programs. Full-time teacherlibrarians are allotted to only teach 6-8 periods a week but should spend 18-20 hours a week to manage SRCs with the assistance of the schools' SRC committee members. However, under-enrolled schools only have parttime teacher-librarians. In addition, schools with enrolment of more than 950 students are allotted a clerk in each school to assist teacher-librarians in managing SRCs. Special category schools such as technical, religious and residential schools are provided with a general worker if the enrolment of students is between 151-500. If these schools have more than 500 students, the teacher-librarins should be provided with a clerk and a general worker to assist them in their day-to-day work.

\section{SRCs development}

Since the SRCs are part of the Educational Technology Division's network as shown in Figure 1, officers at all levels work together as a team to assist the teacher-librarians and their SRCs. Educational Resources Management Department at the ETD plan, manage, coordinate, monitor and evaluate SRC programs including information literacy and reading programs nationwide. At the state level, the Educational Resources Service Unit working with its respective officers from the TACs at district levels, manage, coordinate, implement and monitor the SRC programs and report to the headquarters. (Bahagian Teknologi Pendidikan, 2010). The TACs are also used to gather teacher-librarians and teachers in the districts to collaborate on the latest educational technology and come up with innovative teaching-learning materials (Kementerian Pendidikan Malaysia, 1992).

\section{What is iQ-PSS?}

iQ-PSS is an acronym for the Indeks Kualiti Pusat Sumber Sekolah (Quality Index of School Resource Center). Since IQ also means intelligence quotient, a score derived from standardized tests designed to assess intelligence, it is apt to use the acronym to reflect the 'intelligence' of an SRC.

iQ-PSS is a tool to measure the quality or performance of an SRC. Since it is quite impossible for the STEDs and TACs officers to visit each school due to various reasons such as cost, time and geography, iQ-PSS can assist in setting prioritized services to the SRCs.

\section{The evolution of iQ-PSS as the Quality Management System (QMS) tool}

iQ-PSS is an innovation to improve the management of the Educational Resources Center network which includes school, district, state and national level based on the concept of management information system (MIS). An 'MIS' is a planned system of the collecting, processing, storing and disseminating data in the form of information needed to carry out the functions of management, in this case, specifically, the performance of SRCs.

iQ-PSS is based on the instrument used by the judges for the National SRC Award competition and was once treated as an undisclosed document. The instrument contains both qualitative and quantitative criteria of five main focus areas in SRC:

- Physical, equipment and materials facilities (15\%)

- $\quad$ SRC Management (15\%)

- SRC Usage $(40 \%)$

- Management of NILAM Reading program (20\%)

- SRC Improvement Programs (10\%)

(C) 2010 IASL, SLAQ and therein by the authors. Diversity Challenge Resilience: School Libraries in Action Proceedings of the $12^{\text {th }}$ Biennial School Library Association of Queensland, the $39^{\text {th }}$ International Association of School Librarianship Annual Conference incorporating the $14^{\text {th }}$ International Forum on Research in School Librarianship, Brisbane QLD Australia, 27 September - 1 October 2010. 
In 2006, The ETD adopted the quality management system (QMS) under the umbrella of ISO (the International Organization for Standardization), a worldwide federation of national standards bodies. Therefore, the design and implementation of the ETD's QMS should be based on a process approach when developing, implementing and improving the effectiveness and efficiency of a QMS to enhance SRCs satisfaction by meeting SRCs requirements as shown in Figure 4 (Department of Standards Malaysia, 2000).

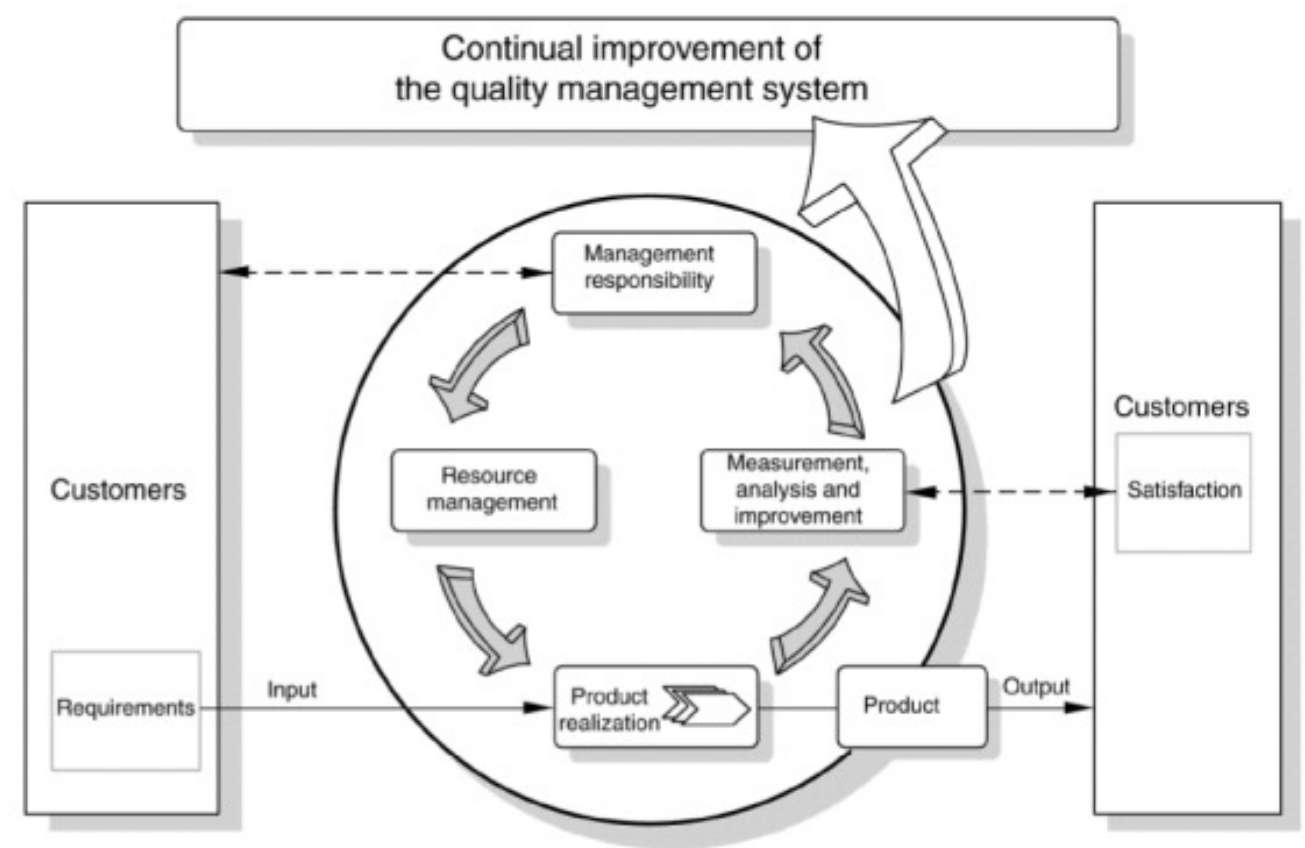

Figure 4. Model of a process-based quality management system. Source: Department of Standards, 2000.

Leading and operating the SRCs nationwide successfully requires systematic management and great coordination from all levels. Combined with the IFLA/UNESCO School Library Guidelines (2002), SRC instrument was exercised and used nationwide under the purview of the Quality Management System (QMS) Standard (MS ISO 9000:2001): SRC Assistance Program's Management. This international standard focuses on the quality and reliability of processes that create products and services, in this case, the management of SRC Assistance Program. To coordinate the management of this program and to ensure the quality of the services and assistance rendered to the SRCs, all states except the Federal Territory of Labuan, registered under the QMS Standard. This also meant that for the first time in history, in 2008, the states began to use a standardized instrument to gauge the performance of SRCs. In the beginning, the instrument was used and filled out manually to find out which SRC receives less than $60 \%$ or 3-star rating and eligible for assistance. The STED and TAC officers had to go to the ground to send out the instruments to teacher-librarians and later collect them back.

Following this success where the use of the instrument was well-coordinated, had made the authors yearned for bigger and more impactful results. Using the advancement of ICT as an enabler, it can be used as a tool to churn out useful information on the management of SRC in real time thus cutting time for data-begging from the states at the time of needs and later spending even more time to add up the figures and change them into analysis and statistics. It was such a drained and frustrating situation time and again! To up the ante, the teacher-librarians are 'forced' to be 'smart' and embrace the Smart School concept. The enculturation of high-tech practices among teacher-librarians is formed. 


\section{iQ-PSS as key performance indicators (KPIs)}

Planning, maintaining, monitoring and evaluating SRCs and SRC programs of a massive system is also a gargantuan task and needs careful considerations of all aspects such as human resources, productivity tools, geography, capital and work values to manage the whole structure. Therefore, the Educational Resources Management Sector must come up with a harmonizing tool for all quarters to work together in keeping its goals aligned. Coordination meetings are held twice a year where officers at each level from each state are welcomed to brainstorm and give views, opinions and ideas to improve on SRC services. Proposals, reports, and analysis of data and activities are also discussed. Resolutions and decisions from these meetings are usually very fruitful as the officers look forward to doing their level best to improve and share best practices from their states with others.

However, the authors observed that the reports and analysis were often activity-based and the outcome of the programs and activities were difficult to measure because of their qualitative nature. The qualities and achievements of SRCs were also not measured by one common yardstick as each state comes up with different standards for grading purposes. The grading guidelines were mostly used for SRCs which wishes to take part in the National SRC Excellent Award. Therefore, not all SRCs were measured in terms of performance and data on the achievement of SRCs were often conflicting (Saidatul Akmar \& Halida, 2007).

The Malaysian Civil Service is capable of attaining world-class delivery of service through the implementation of programs which focus on five areas: continuous improvement, good work ethics, developing knowledgeable and skilled human capital, performance-based work culture and strong leadership (Jabatan Perdana Menteri Malaysia, 2005). KPIs are quantifiable metrics that reflect the performance of an organization in achieving its goals and objectives. It is a performance management tool which possesses the following characteristics:

- KPIs reflect strategic value drivers to achieve organizational goals

- KPIs are quantifiable based on valid data and standards

- KPIs lead to positive actions and key to organizational success

Saidatul Akmar and Halida (2007) recommended that key performance indicators (KPIs) should be employed and made compulsory in a work culture that is performance-based at all levels of Malaysian Civil Service, including the SRCs. Employing KPIs in the SRCs can be a starting point towards SRC improvement to ensure high level of performance.

\section{iQ-PSS features}

iQ-PSS is an outsourced web-based system developed using open-source technology. With a cost of less than RM 5.00 per school, iQ-PSS is one of the modules in the online Integrated Educational Resources Management's framework (Pengurusan Sumber Pendidikan Bersepadu) as shown in Figure 5. 


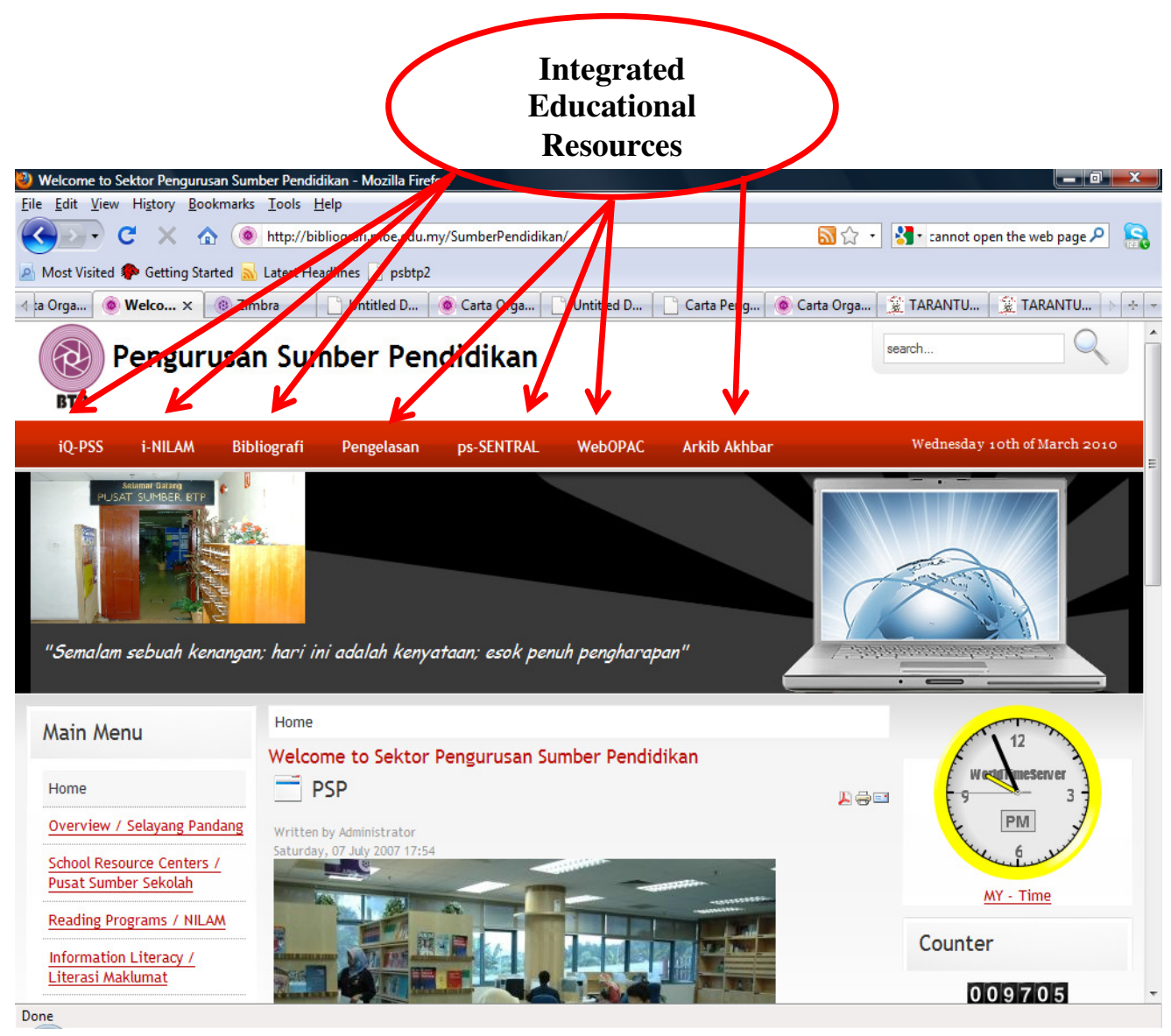

Figure 5. Integrated Educational Resouces homepage. Source: Bahagian Teknologi Pendidikan, 2010.

iQ-PSS has the following characteristics:

- The system is built based on the open-source technology

- It can cater unlimited users

- The system can be accessed simultaneously

- The system is based on web-technology

- The system has high level of security features

- Data entry processing is done by teacher-librarians online instead of filling out the instrument manually. (Schools without Internet access can fill out the instrument manually and send it to their respective TAC officers for data-entry process)

- STEDs and TACs officers can monitor the data entered by teacher-librarians and update the data if there is a need. They can also give suggestions and comments on SRCs under their administration

- STEDs and TACs officers can observe the data of all schools under their administration. For example, the best SRC in the district or state can be nominated as a model SRC whereas low-ranking SRCs 2-star and below can be selected for the SRC Assistance program

- At the headquarters, ETD can use the information from iQ-PSS to decide on SRCs strategic planning and future directions. 
- iQ-PSS can be used to transform data into information useful for decision making. It can provide performance reports to assist in the planning, monitoring and implementation of strategy.

- iQ-PSS provides a valuable function in that they can collate into coherent reports unmanageable volumes of data that would otherwise be broadly useless to decision makers. By studying these reports, decision-makers and policy makers can identify patterns and trends that would have remained unseen if the raw data were consulted manually.

- Not only does iQ-PSS allow for the collation of vast amounts of SRCs data, but it also provides a valuable time saving benefit to the workforce of ETD and its network. Where in the past information on SRCs had to be manually processed for filing and analysis, it can now be entered quickly and easily online, allowing for faster decision making and quicker reflexes for the ETD as a whole.

- While iQ-PSS is extremely useful in generating statistical reports and data analysis, it can also be used as a Management by Objectives (MBO) tool which is set using the SMART ratio: that is, objectives should be Specific, Measurable, Achieveable, Realistic and Time-Specific. The aim of these objectives is to provide a set of key performance indicators by which the ETD can judge the performance of a project, program or activity. iQ-PSS is useful to track SRCs performance. Since all SMART objectives are by definition measurable they can be tracked through the generation of management reports to be analyzed by decision-makers and policy makers.

\section{Scope and workflow of iQ-PSS}

iQ-PSS involves the following entities:

- All schools in Malaysia

- 367 Teacher Activity Centers

- 15 State Educational Technology Divisions

- Educational Resources Management Sector

- Educational Technology Division

iQ-PSS workflow is depicted in the following diagram.

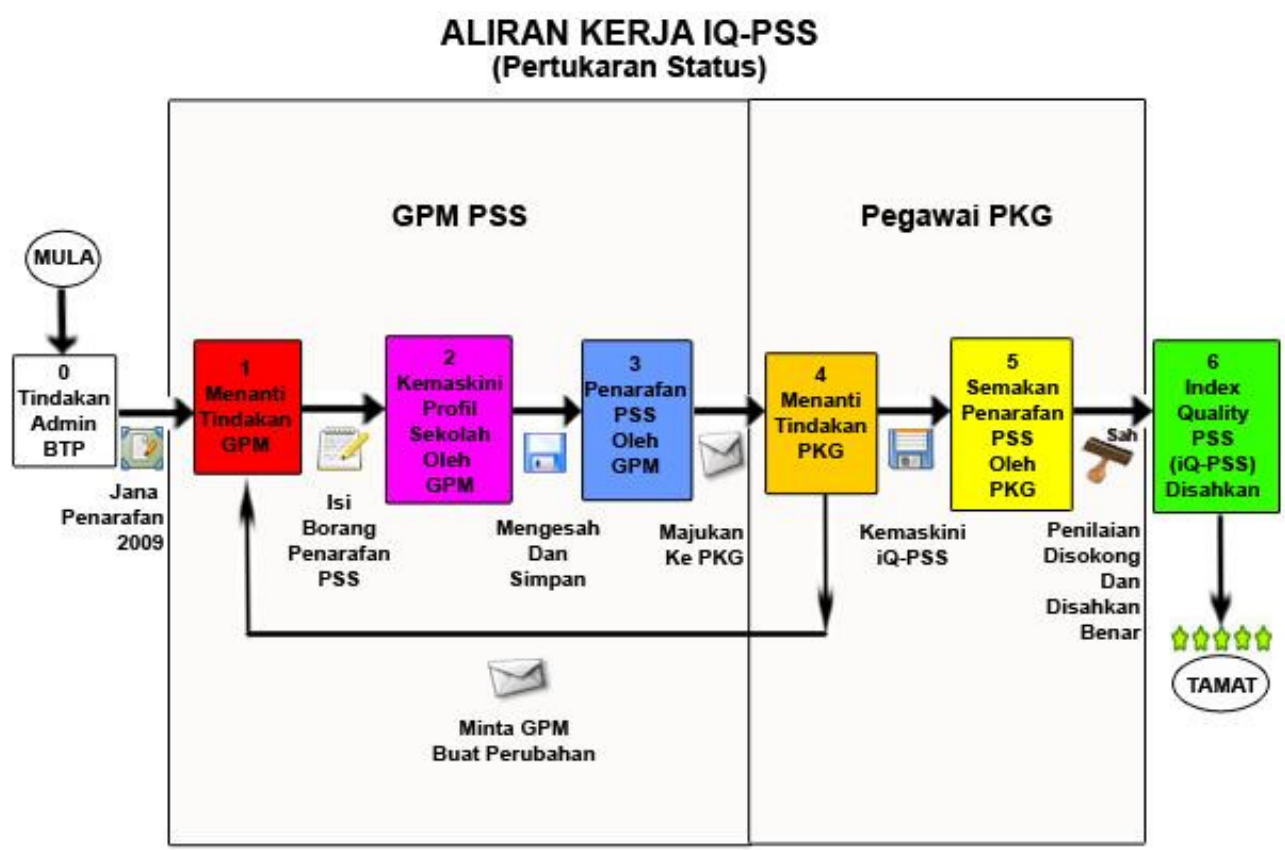

Figure 6. iQ-PSS workflow. Source: http://btp.tarantula.my/system_iq-pss/

(C) 2010 IASL, SLAQ and therein by the authors. Diversity Challenge Resilience: School Libraries in Action Proceedings of the $12^{\text {th }}$ Biennial School Library Association of Queensland, the $39^{\text {th }}$ International Association of School Librarianship Annual Conference incorporating the $14^{\text {th }}$ International Forum on Research in School Librarianship, Brisbane QLD Australia, 27 September - 1 October 2010 


\section{Findings}

Overall status

$\mathbf{6 , 2 5 8}(\mathbf{6 3 . 6 \%})$ out of 9,843 registered schools were successfully rated. However, 3,585 (36.4\%) schools are at various stages in the process of completing iQ-PSS as shown below.

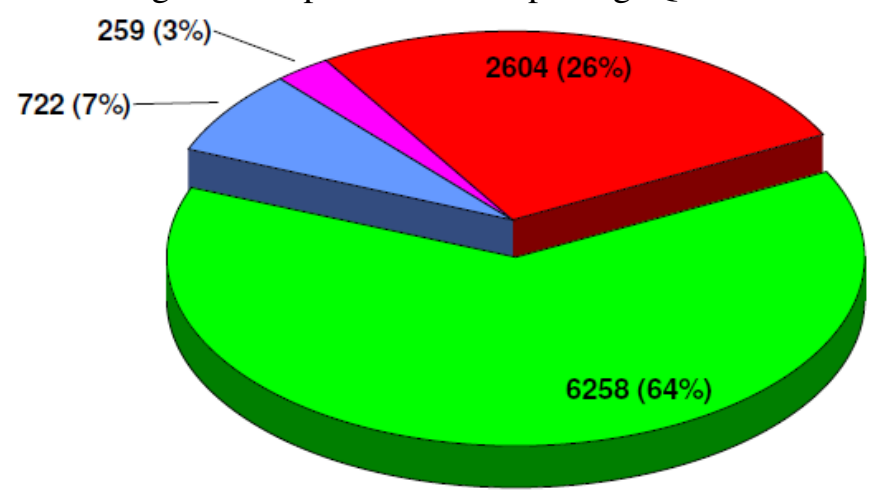

\begin{tabular}{|c|c|c|}
\hline & iQ-PSS Status & No. of SRCs \\
\hline 1. & TLs' Action Required & 2604 \\
\hline 2. & Updating School Profile by TLs & 259 \\
\hline 3. & Self-evaluation by TLs & 722 \\
\hline 6. & Endorsed iQ-PSS & 6258 \\
\hline & Total & 9843 \\
\hline
\end{tabular}

Figure 7. iQ-PSS Overall Status

Only four (4) states completed all stages of iQ-PSS. They are Kedah (700), Melaka (304), Pulau Pinang (392) dan WP Labuan (26).

However, another four (4) states have low percentage of completed iQ-PSS. Negeri Sembilan only completed $229(50 \%)$ from a total of 458 SRCs, Perak completed $528(48.8 \%)$ from a total of 1,083 SRCs, Sabah completed 240 (18.9\%) out of 1,271 PSS and Sarawak 637 (44.2\%) out of 1,440 SRCs. Therefore, it is quite difficult to gauge the SRCs performance and get the whole picture at state level.

\begin{tabular}{|c|c|c|c|c|c|}
\hline \multicolumn{6}{|c|}{ iQ-PSS Status } \\
\hline STEDs & $\begin{array}{l}\text { No. of } \\
\text { SRCs }\end{array}$ & $\begin{array}{c}1 . \\
\text { TLs' Action } \\
\text { Required }\end{array}$ & $\begin{array}{c}2 . \\
\text { Updating } \\
\text { School Profile } \\
\text { by TLs }\end{array}$ & $\begin{array}{c}3 . \\
\text { Self-evaluation } \\
\text { by TLs }\end{array}$ & $\begin{array}{c}6 . \\
\text { Endorsed iQ- } \\
\text { PSS }\end{array}$ \\
\hline Johor & 1129 & 252 & 47 & 88 & 742 \\
\hline Kedah & 700 & & & & 700 \\
\hline Kelantan & 551 & 19 & 32 & 63 & 437 \\
\hline Melaka & 304 & & & & 304 \\
\hline Negeri Sembilan & 458 & 156 & 14 & 59 & 229 \\
\hline Pahang & 707 & 13 & 8 & 13 & 673 \\
\hline Perak & 1083 & 431 & & 124 & 528 \\
\hline
\end{tabular}

(C) 2010 IASL, SLAQ and therein by the authors. Diversity Challenge Resilience: School Libraries in Action Proceedings of the $12^{\text {th }}$ Biennial School Library Association of Queensland, the $39^{\text {th }}$ International Association of School Librarianship Annual Conference incorporating the $14^{\text {th }}$ International Forum on Research in School Librarianship, Brisbane QLD Australia, 27 September - 1 October 2010. 


\begin{tabular}{|c|c|c|c|c|c|}
\hline Perlis & 101 & 5 & & 4 & 92 \\
\hline Pulau Pinang & 392 & & & & 392 \\
\hline Sabah & 1271 & 839 & 83 & 109 & 240 \\
\hline Sarawak & 1440 & 630 & 34 & 139 & 637 \\
\hline Selangor & 907 & 123 & 8 & 29 & 747 \\
\hline Terengganu & 481 & 72 & 27 & 62 & 320 \\
\hline WP Kuala Lumpur & 293 & 64 & 6 & 32 & 191 \\
\hline WP Labuan & 26 & & & & 26 \\
\hline Total & 9843 & 2604 & 259 & 722 & 6258 \\
\hline
\end{tabular}

Figure 8. iQ-PSS Overall status according to state

\section{Location}

As mentioned earlier, each school has SRC. As of December 2009, there are 7,652 (77.7\%) primary schools and 2191 (22.3\%) secondary schools in Malaysia. 2,034 (20.7\%) schools are located in the urban areas whereas $7,809(79.3 \%)$ schools are located in the rural areas.

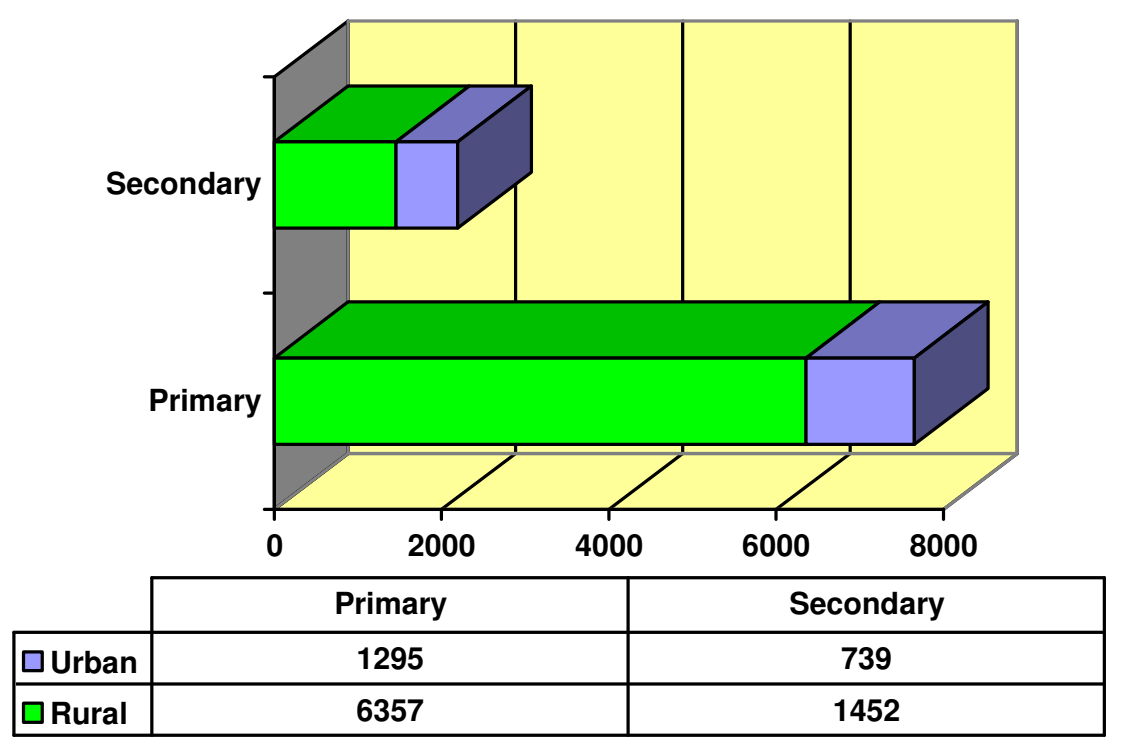

Figure 9. SRCs in Malaysia.

\section{SRCs infrastructure}

Based on the report of 8,079 respondents, 3,393 (42\%) SRCs are located in specially designed rooms, 3,215 (40\%) SRCs are situated in modified rooms, $626(8 \%)$ SRCs are placed in specially designed buildings while $647(8 \%)$ SRCs are located in modified buildings. However, $198(2 \%)$ respondents didn't mention the location of the SRCs. 


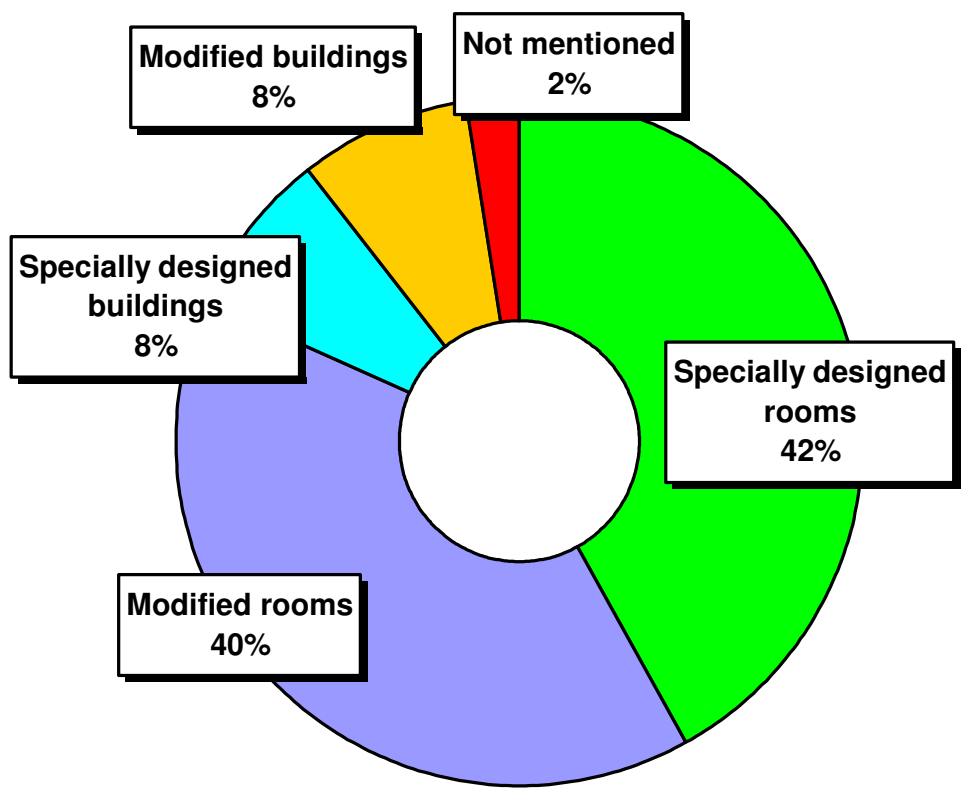

Figure 10. SRC infrastructure.

SRCs rating based on $i Q-P S S$

6,258 SRCs were successfully rated. PSS. 214 (3.4\%) SRCs accomplished 5-star rating which is equivalent to 85-100\% marks based on the instrument. 799 (12.8\%) SRCs achieved 4-star rating or $70-84 \%$ marks and 1135 (18.1\%) SRCs received 3-star rating or $60-69 \%$ marks. However, 2,015 (32.2\%) SRCs are still in less than satisfacory condition as they achieved 2-star or $45-59 \%$ marks and $\mathbf{2 , 0 9 5}(\mathbf{3 3 . 5 \%})$ SRCs are unsatisfactory with 1-star or $0-44 \%$ marks.

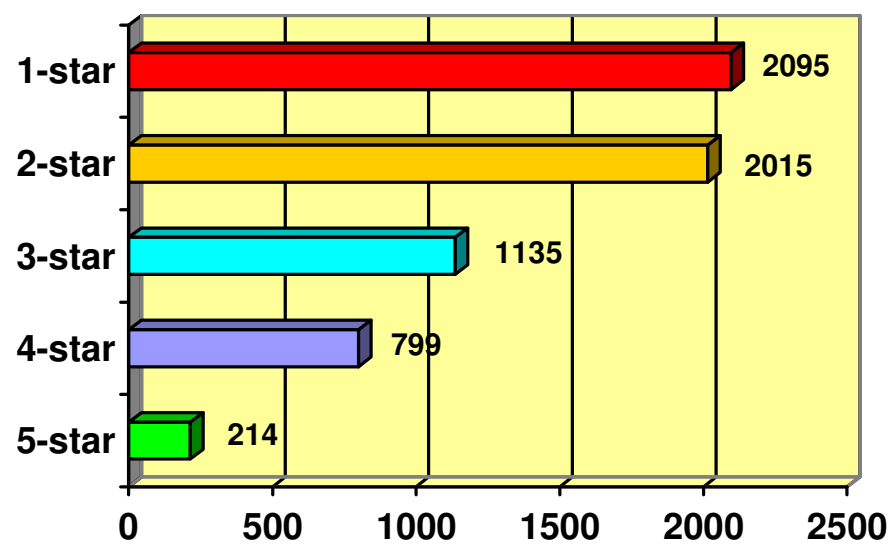

Figure 11. iQ-PSS Rating.

(C) 2010 IASL, SLAQ and therein by the authors. Diversity Challenge Resilience: School Libraries in Action Proceedings of the $12^{\text {th }}$ Biennial School Library Association of Queensland, the $39^{\text {th }}$ International Association of School Librarianship Annual Conference incorporating the $14^{\text {th }}$ International Forum on Research in School Librarianship, Brisbane QLD Australia, 27 September - 1 October 2010 
SRC rating based on categories

A detailed analysis is needed to study the strengths and weaknesses of SRCs in depth so that decisions on any corrective action to improve SRCs can be done.

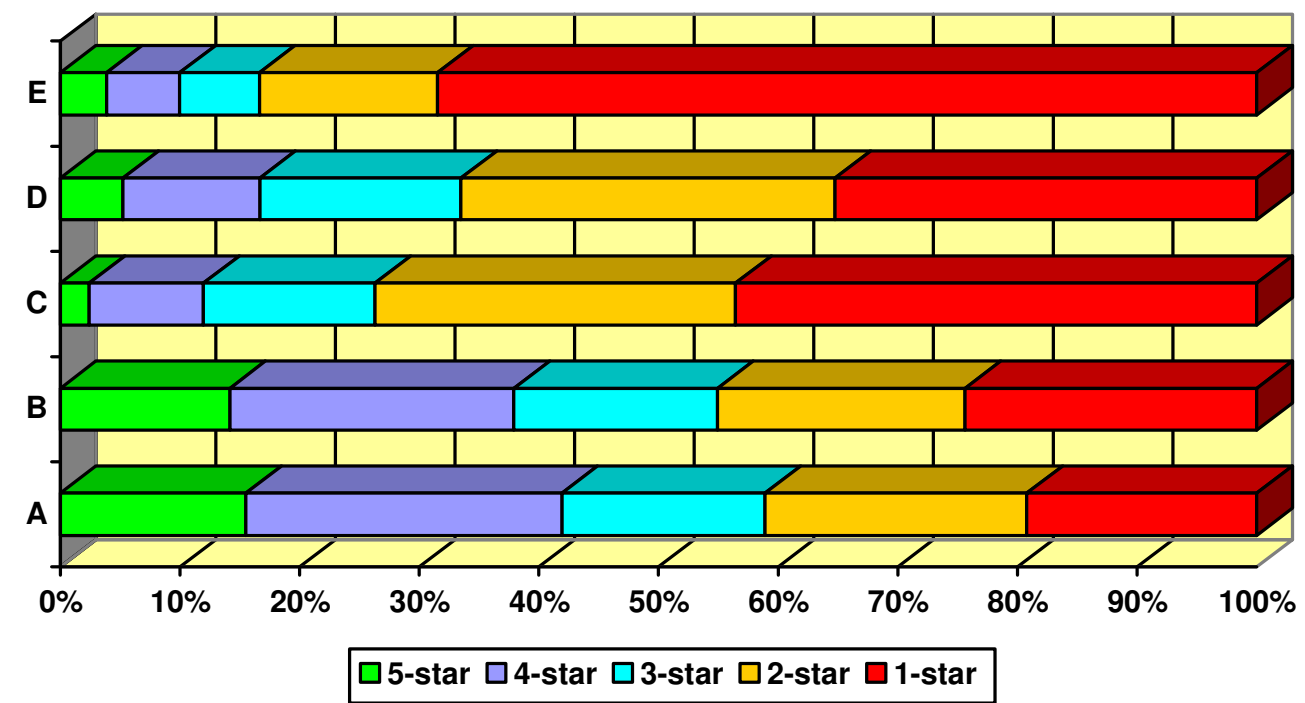

\section{Figure 12. iQ-PSS rating according to category.}

\section{Section A - Physical, equipment and materials facilities}

The location of the SRC, layout of rooms and spaces, furniture and furnishings, extra spaces and facilities, materials on the various format such as printed, non-printed, electronic equipment and security features are graded under this section. It carries $15 \%$ of the total score of iQ-PSS. The analysis shows that $\mathbf{3 , 6 8 6}(\mathbf{5 8 . 9 \%})$ SRCs achieved 3-star and above which means that basically, the SRCs have good physical, equipment and materials facilities.

\section{Section B - Management and administration of SRC}

Section B concentrates on the management and administration of SRC which includes organizational structure, yearly planning, finances, records and documentation, collection, equipment, and involvement of school community and other agencies in SRC media programs. This section also carries $15 \%$ of the total score of iQPSS. iQ-PSS indicated that 3,438 (55.9\%) SRCs attained 3-star and above. This means that a little bit more than half SRCs have good day-to-day SRC management.

\section{Section C - SRC usage}

This section carries the most weight in the instrument, $40 \%$ out of the total score. It details out the operation hour, duty rosters of SRC committees, circulation, usage, exhibition, awareness and promotional activities, selfaccessed learning, media and information literacy programs and production of materials and software for teaching-learning. iQ-PSS demonstrates that only 1,646 26.3\% SRCs achieved the score of 3-star and above. The analysis shows that only $1 / 4$ SRCs give good services to the school communities. 
Section D - Management of NILAM reading program

NILAM is a year-round integrated reading program first implemented in 1998 where students are encouraged to record their reading activities and received reward and recognition. The main objective of this program is to inculcate reading habit among school children.

This section is significant to ensure the success of NILAM program in schools. Among the items graded are the management of NILAM, students' involvement and achievement, management of records and documents, and types of reward and recognition given to students who have shown commitment in the program throughout their schooling years. Only $\mathbf{2 , 0 9 7}(\mathbf{3 3 . 5 \%})$ SRCs have good management of NILAM reading program as they achieved 3 -star rating and above.

\section{Section E - SRC improvement programs}

To ensure continuous improvement of SRCs, this section evaluates the effectiveness of SRC programs which includes SRC strategic planning, long-term financial planning and staff development programs. iQ-PSS shows that only $1,042(\mathbf{1 6 . 7 \%})$ SRCs have good strategy for continuous improvement as they have the rating of 3-star and above.

\section{SRC automation}

Day-to-day SRC management and services can be improved and made more efficient by having library automation. Other than that, it helps create a better awareness of ICT utilization and spawn interest in information-related programs conducted by the schools. 7,959 (99\%) out of 8,079 SRCs reported that they use automation which is really a pleasant surprise. It shows that the efforts of various quarters to promote effective library management using ICT as an enabler is fruitful and supported by the teacher-librarians.

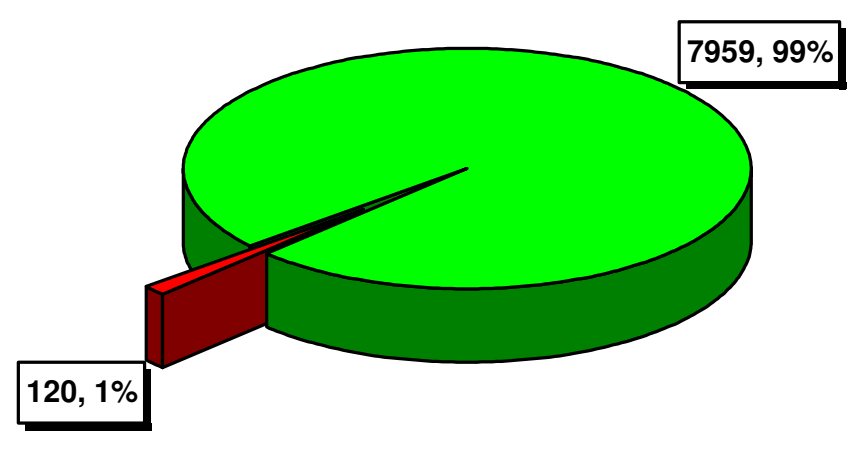

Figure 13. Library automation.

\section{Book collection}

Book collection is one of the most important features in SRC as it is looked upon as a tool to increase access and equality in education. The Ministry of Education has stated that primary schools should have 1:15 book ratio whereas secondary schools should have 1:20. 


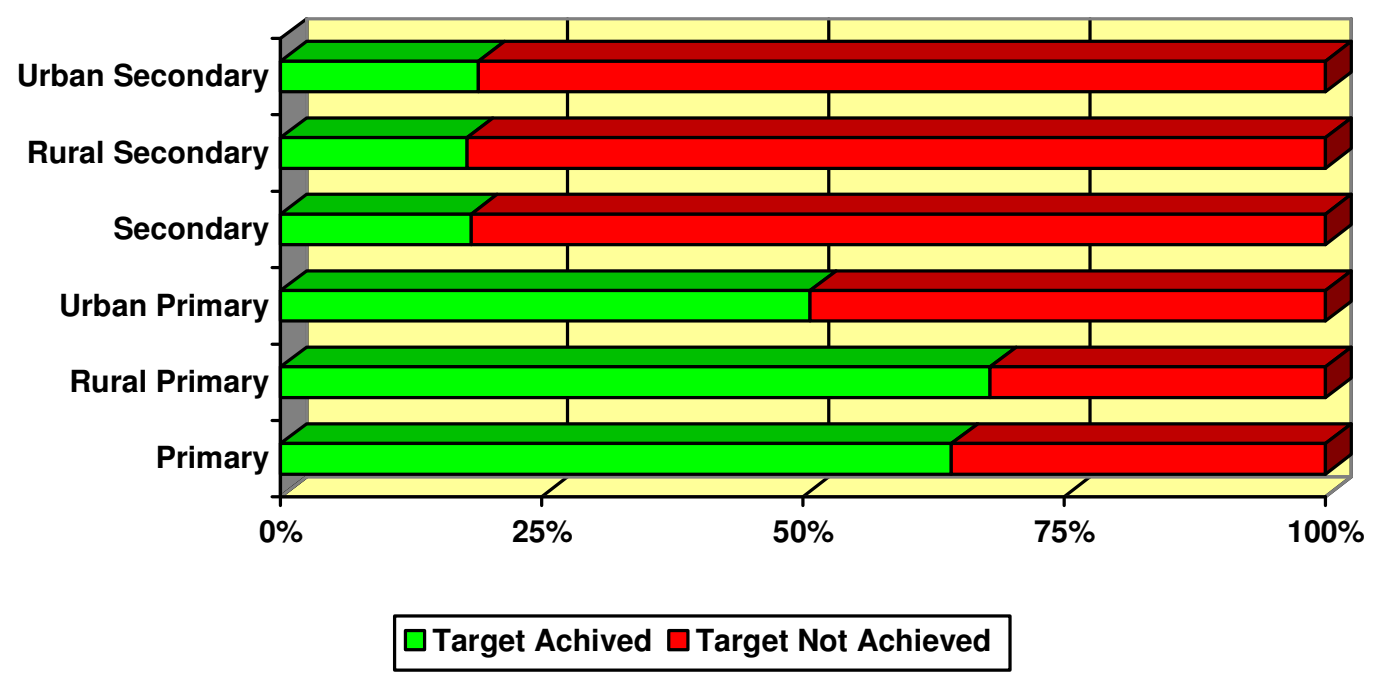

Figure 14. Book collection in SRCs.

iQ-PSS shows that based on a total of 6,017 respondents, $\mathbf{2 , 9 0 4}(\mathbf{6 4 \%})$ out of 4,521 primary schools have achieved the book ratio of 1:15 whereas only $\mathbf{2 7 3}(\mathbf{1 8 \%})$ out of 1,496 secondary schools have achieved 1:20 book ratio.

The analysis according to location indicated that rural primary schools have more book collection per student compared to urban primary schools. $\mathbf{2 , 4 1 5}(\mathbf{6 8 \%})$ out of 3,556 rural primary schools have achieved the target while only $489(51 \%)$ out of 965 urban primary schools have reached the standard.

The status of secondary schools either in rural or urban area doesn't make that much different. Only $\mathbf{1 8 7}$ (18\%) out of 956 rural secondary schools have a book collection of 1:20 while $\mathbf{1 0 6}(\mathbf{1 9 \%})$ out of 560 urban secondary schools have achieved the standard.

There are several factors contributing to this scenario. Rural primary schools have less number of students compared to urban primary schools thus making it easier to achieve the standard of 1:15. On the other hand, secondary schools are often concentrated in cities or big towns even if they are in rural areas and have quite a number of students' enrolment. By having this analysis, the perception that book donations should be given to rural primary schools have somewhat altered since it is the students of secondary schools both in rural and urban areas who are in need of books in their SRCs the most.

\section{Teacher-librarians}

Teacher-librarians are the main agents for the success and the fall of SRCs in Malaysia. They are important players in moving the SRCs towards encouraging information-based learning to students and teachers in schools.

\section{a. $\quad$ Teacher-librarian competencies}

A competent teacher-librarian understands and appreciates the concept and philosophy of SRC as a knowledge institution. Even though there is no policy for trained teacher-librarians in Malaysia yet, efforts are undertaken to ensure teacher-librarians are given training in library science and information management to assist them in doing their day-to-day job. 


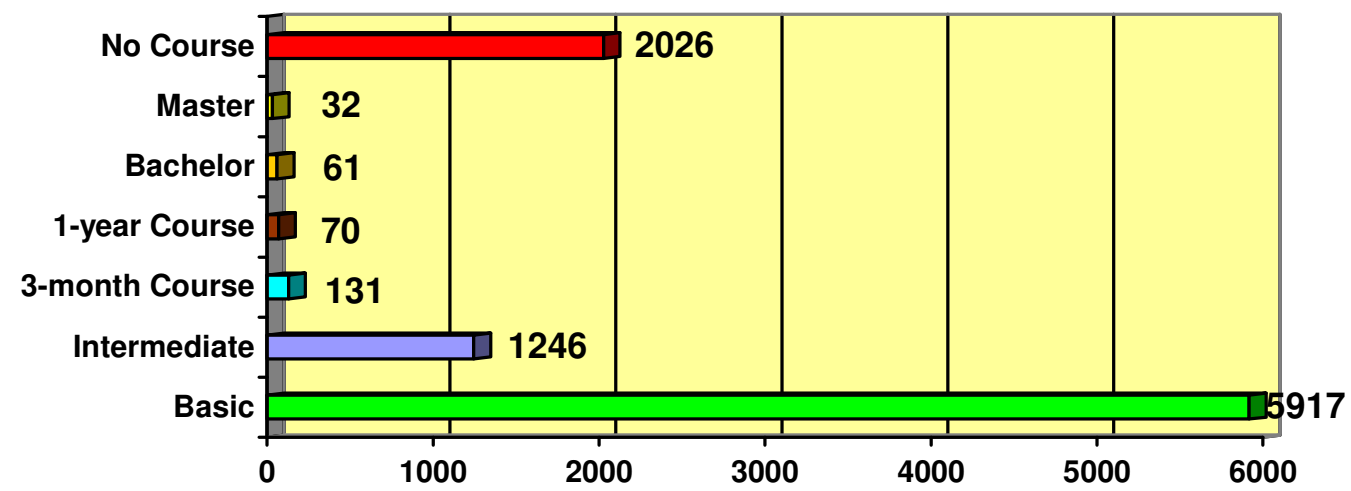

Figure 15. Teacher-librarian competencies.

iQ-PSS shows that 5,917 (73\%) teacher-librarians have attended the 35-hour Basic SRC Management course which includes topics on educational technology, SRC concept, facilities, services and management. It also touches on the management of NILAM reading program. On the other hand, 2026 (25\%) teacher-librarians have yet to undergo any SRC training. This is quite worrying as the number of teacher-librarians' turnover is still quite high even though several measures have been taken to reduce the situation.

b. Teacher-librarian experiences

$\mathbf{3 , 5 8 4}(\mathbf{4 4 \%})$ out of 8,079 teacher-librarians have vast experiences in pedagogy as they have been in the education field for more than 10 years. They can integrate and use their knowledge to collaborate with and assist teachers to use and develop teaching-learning materials. They can also act as a consultant in promoting best practices and educational resources integrations in the classrooms. On the other hand, $\mathbf{2 , 8 9 3}(\mathbf{3 6 \%}$ ) teacher-librarians have been teaching for five years or less. There is a tendency for school administrators to keep on changing and select new teachers as teacher-librarians as managing SRC is sometimes perceived as tough and not many teachers are keen to be teacher-librarians or the teacherlibrarians are needed for their expertise to teach examination classes.

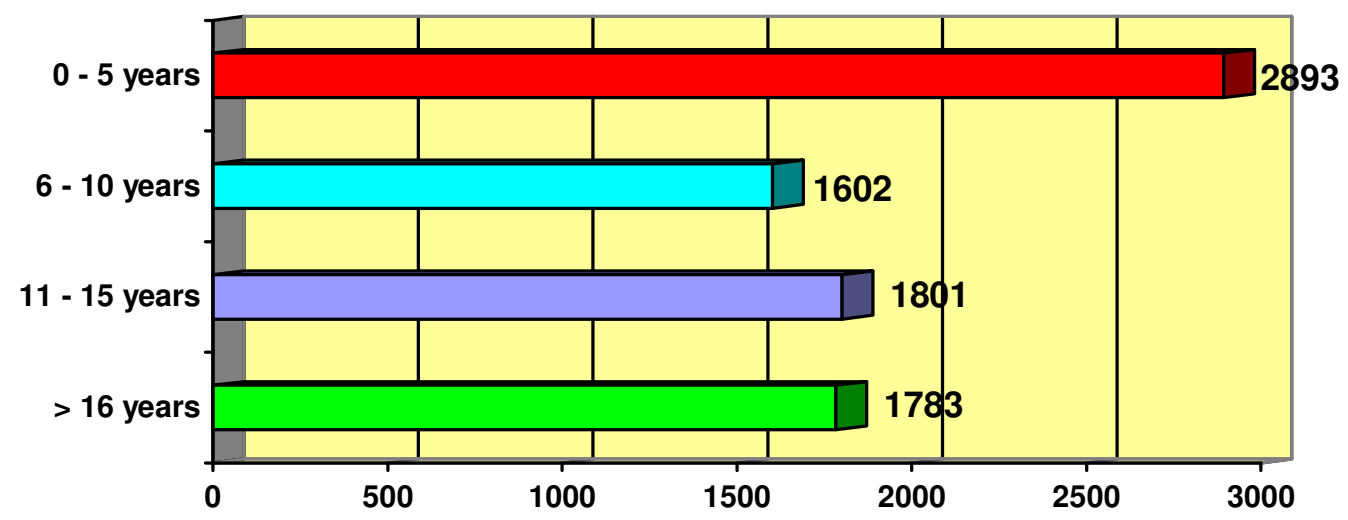

Figure 16. Teacher-librarians' experience

(C) 2010 IASL, SLAQ and therein by the authors. Diversity Challenge Resilience: School Libraries in Action Proceedings of the $12^{\text {th }}$ Biennial School Library Association of Queensland, the $39^{\text {th }}$ International Association of School Librarianship Annual Conference incorporating the $14^{\text {th }}$ International Forum on Research in School Librarianship, Brisbane QLD Australia, 27 September - 1 October 2010 . 


\section{c. $\quad$ Teacher-librarians grades}

Even though the circular stated that primary school teacher-librarians should be given to those with DGA 29 (entry level teachers with diploma in education) and secondary school teacher-librarians should be those with DG 41 (entry level teachers with a degree and diploma in education), iQ-PSS show that higher-positioned teachers are also teacher-librarians (Kementerian Pelajaran Malaysia, 2005).This could be due to the fact that these teacher-librarians are still interested in managing SRCs and there are not many opportunities for senior positions in schools.

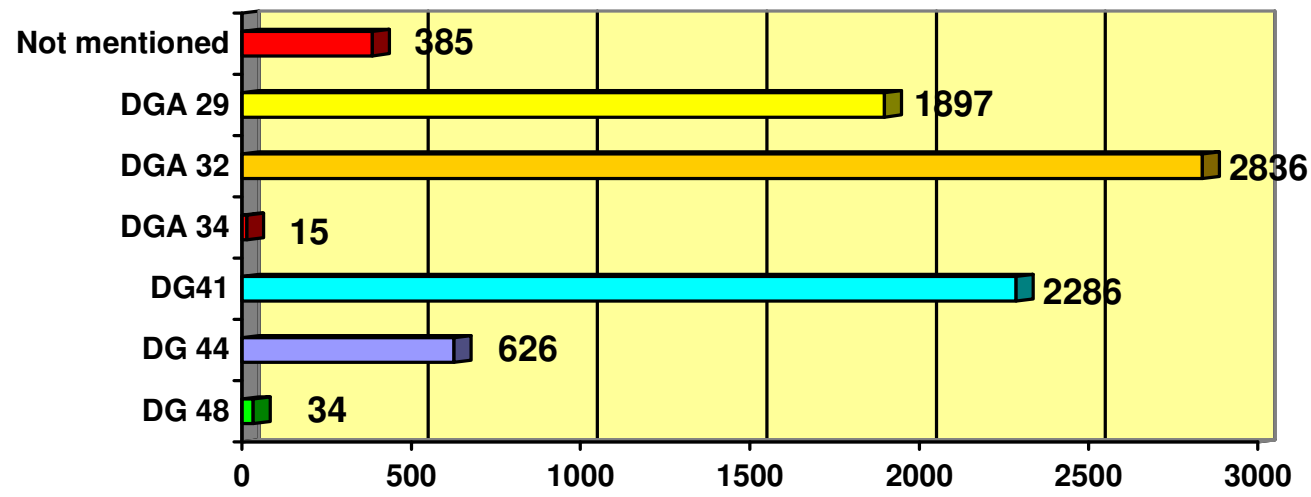

Figure 1. Teacher-librarians grades.

Efforts are taken to maintain senior teacher-librarians in their positions so as to deter further 'brain drain' in SRCs. Teacher-librarians with three years of experience managing SRCs are eligible for Excellent Teachers in SRC category. They can still maintain their position as teacher-librarians even though their grades have reached equivalent to senior principles / headmasters.

\section{d. Teacher-librarians workload}

Even though there is a circular stating that teacher-librarians should only teach $6-8$ periods a week and another $18-20$ periods a week to manage and focus on the development of SRCs, iQ-PSS indicates that $\mathbf{7 , 4 4 2}(\mathbf{8 5 . 5 \%})$ teacher-librarians teach more than the required periods. 3,284 (40.6\%) teacher-librarians reported that they teach more than 20 periods a week (Kementerian Pelajaran Malaysia, 2005). 


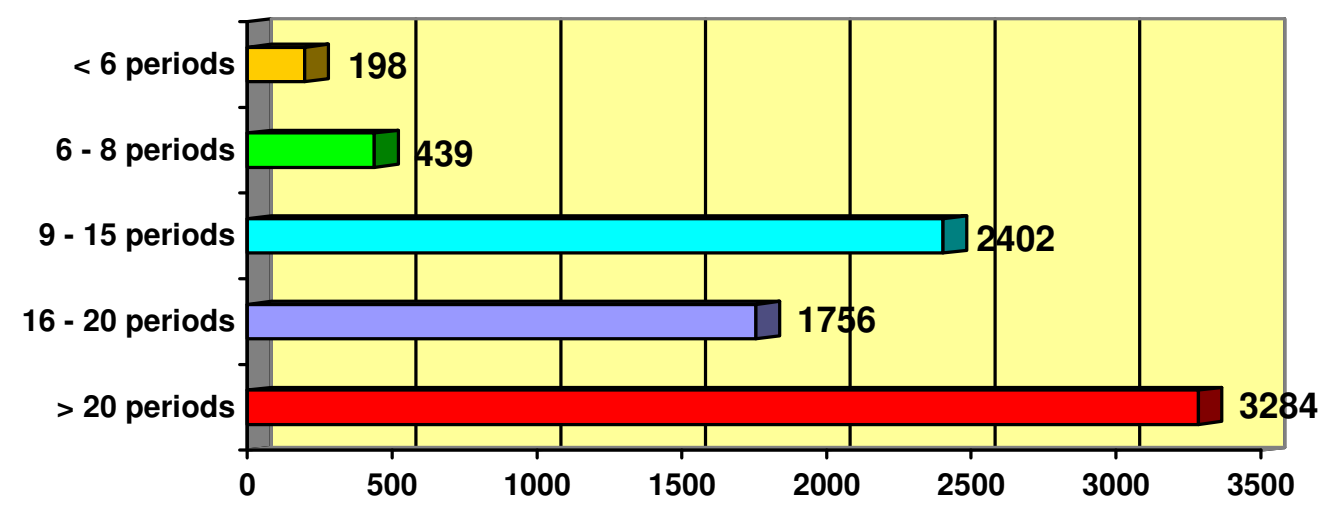

Figure 2. Teacher-librarians' teaching periods.

Efforts to highlight the importance of releasing teacher-librarians from heavy workload are somewhat hindered by the outlook of some quarters even though reminders are sent out and the matters discussed in top-level meetings.

e. $\quad$ Teacher-librarians appointments

Teacher-librarians are given special appointment letters to reduce the number of turnovers which could affect the SRC management (Kementerian Pelajaran Malaysia, 2008). These letters are under the purview of the Directors of State Education Departments.

iQ-PSS shows that 3,401 (42.1\%) out of 8,079 respondents have been given appointment letters while the rest have been appointed by their respective school heads.

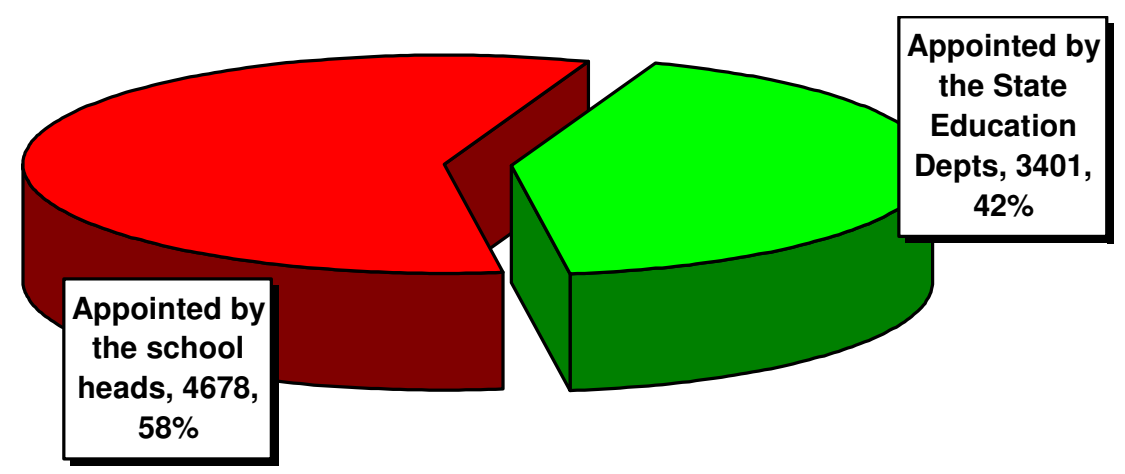

Figure 3. Teacher-librarians appointments.

\section{Recommendations}

iQ-PSS as a measurement to the standards of SRCs, is only the beginning and not the end of the journey to SRC excellence. Its impact is so great that it provides useful information for decision-making on the development of SRCs. However, in order for this star-ranking system to yield intended results, it is recommended that all quarters to work as a team and cooperate towards the success of iQ-PSS implementation.

- Teacher-librarians should be honest in giving the information on their respective SRCs as the main objective of this system is to assist their SRCs either in the short-run or for long-term planning. 
- The school administrators should support their respective teacher-librarians as these teachers are the main players for the enculturation of ICT through the Smart School concept and, the inculcation of reading habits and life-long learning.

- At the district level, TAC officers should monitor and assist the progress of iQ-PSS implementation. They should also verify the standards of SRCs at random to ensure accurate results.

- At the state level, STED officers should coordinate the implementation of iQ-PSS with the TAC officers. They should monitor and evaluate the performance of SRCs and give appropriate supports in the programs and activities.

- ETD as the headquarters should ensure that the information highway runs smoothly by providing access to the Internet to all schools $24 \times 7$ and lay a strong foundation in ICT infrastructure. The information from iQ-PSS should be reported to the top-level officers and used to propose preventive and corrective actions to ensure continuous improvement of SRCs.

\section{Conclusion}

iQ-PSS, first introduced in July 2009, is a tool to monitor and coordinate the development of the School Resource Centers throughout Malaysia. Using ICT as an enabler and open-source technology as cost-optimizer, iQ-PSS has successfully achieved a new terrain in supporting effective delivery of public services, mainly in education. With this systematic monitoring, it is hoped that any decision relating to the development of SRCs can be made accurately and meet the needs of users.

iQ-PSS has opened up new horizon in embracing the School Resource Centers of the future. By applying the same concept as iQ-PSS, SRCs can be linked together all over the country, and their educational resources can be explored, accessed and shared among teachers and students, anytime anywhere, ubiquitously. At the moment, the ETD is implementing new initiatives based on the same framework:

- i-NILAM, an online student-reading activity databases

- ps-Sentral, an online library automation

- online educational resources portal

- online newspaper archive (education articles)

- online Dewey classification system both in Malay and English languages

Even though there are several hiccups in the implementation of all initiatives such as ICT knowledge and readiness among teacher-librarians, commitment of administrators of all levels and financial factors, the embodiment of the spirit to change is there. It just needs a spark to ignite the fire of transformation as Malaysia is fast approaching 2020. Smart School concept, world-class education system and Vision 2020 can be achieved not by being rhetoric but they need shared vision, flexible organization of implementers at ground level, welldefined deliverables, performance-based management, continuous improvement and customer satisfaction which act as puzzle pieces of quality management standards. 


\section{References}

Bahagian Teknologi Pendidikan. (2008). Kertas Cadangan Program Penarafan Pusat Sumber Sekolah Malaysia. (unpublished), Kuala Lumpur: Bahagian Teknologi Pendidikan, Kementerian Pelajaran Malaysia.

Bahagian Teknologi Pendidikan. (2009). Laporan Keseluruhan Pelaksanaan Khidmat Bantu Pusat Sumber Sekolah (PSS) 2009. (unpublished), Kuala Lumpur: Bahagian Teknologi Pendidikan, Kementerian Pelajaran Malaysia.

Bahagian Teknologi Pendidikan. (2010). Portal rasmi Bahagian Teknologi Pendidikan. Retrieved from http://www.moe.edu.my:8080/web/guest/home

Department of Standards Malaysia. (2000). Quality Management Systems - Guidelines for performance improvements $\left(2^{\text {nd }} e d\right.$.). Shah Alam: SIRIM Berhad.

Fatimah Jusoh. (2002). School libraries in Malaysia. In: Singh, D et al (Eds.), School libraries for a knowledge society, Proceedings of the 31st. IASL Annual Conference and 6th International Forum on research in school librarianship, 5-9 August, Petaling Jaya, Malaysia.

International Federation of Library Associations. (2002). IFLA/UNESCO School Library Guidelines. Retrieved from http://archive.ifla.org/VII/s11/pubs/sguide02.pdf

Jabatan Perdana Menteri Malaysia. Pekeliling Kemajuan Pentadbiran Awam bil. 2 tahun 2005: Garis panduan bagi mewujudkan petunjuk-petunjuk presatsi utama atau key performance indicator (KPI) dan melaksanakan pengurukuran prestasi di agensi kerajaan. Putrajaya: Jabatan Perdana Menteri Malaysia.

Kaur, Kiran. (2007). MS ISO 9001:2000 Implementation in Malaysian Academic Libraries. In: Building An Information Society For All: Proceedings of the International Conference on Libraries, Information and Society, ICOLIS 2007, 26-27 June 2007, Armada Hotel, Petaling Jaya, Malaysia.

Kementerian Pelajaran Malaysia. (2000). Surat Pekeliling Ikhtisas Bil. 10/2000: Tahun Pusat Sumber Sekolah (PSS) 2000. Kuala Lumpur: Kementerian Pelajaran Malaysia.

Kementerian Pelajaran Malaysia. (2005). Surat Pekeliling Ikhtisas Bil. 3/2005: Penyelarasan Waktu Mengajar Guru Perpustakaan \& Media. Kuala Lumpur: Kementerian Pelajaran Malaysia.

Kementerian Pelajaran Malaysia. (2008). Minit Mesyuarat Jawatankuasa Induk Gerakan Tabiat Membaca Kementerian Pelajaran Malaysia Bil. 2/2008. (unpublished). Kuala Lumpur: Kementerian Pelajaran Malaysia.

Kementerian Pelajaran Malaysia. (2010). Statistik. Retrieved from http://www.moe.gov.my/

(C) 2010 IASL, SLAQ and therein by the authors. Diversity Challenge Resilience: School Libraries in Action Proceedings of the $12^{\text {th }}$ Biennial School Library Association of Queensland, the $39^{\text {th }}$ International Association of

School Librarianship Annual Conference incorporating the $14^{\text {th }}$ International Forum on Research in School

Librarianship, Brisbane QLD Australia, 27 September - 1 October 2010. 
Kementerian Pendidikan Malaysia, Bahagian Teknologi Pendidikan. (1992). Pusat Kegiatan Guru: Konsep dan pengoperasian. Kuala Lumpur: Kementerian Pendidikan Malaysia.

Mahathir Mohamad. (1991). Working Paper at the Malaysian Business Council: The Way Forward - Vision 2020. Retrieved from http://www.wawasan2020.com/vision/

Ministry of Education. (1997). The Malaysian Smart School: A conceptual blueprint. Kuala Lumpur: Ministry of Education.

MSC Malaysia. (2005). Malaysian smart school roadmap 2005-2020: An educational odyssey. Selangor: Multimedia Development Corporation.

Saidatul Akmar Ismail, and Halida Yu, (2007) Key Performance Indicators for School Resource Centre (SRC) Improvement. In: Building An Information Society For All: Proceedings of the International Conference on Libraries, Information and Society, ICOLIS 2007, 26-27 June 2007, Armada Hotel, Petaling Jaya, Malaysia.

Yusup Hashim \& Razmah Man. (2005). Teknologi instruksional: teori dan aplikasi $\left(2^{\text {nd }} e d\right)$. Tanjong Malim: Syarikat Perintis. 